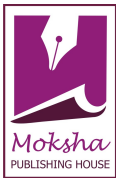

Review Article

www.ijrap.net

\title{
UNDERSTANDING OF GERIATRIC ANEMIA (PANDU ROGA IN OLD AGE): AN AYURVEDIC PERSPECTIVE
}

\author{
Megha G. Pandya *1, Alankruta R. Dave ${ }^{2}$ \\ ${ }^{1}$ Lecturer, Department of Kayachikitsa, Shri Gulabkunverba Ayurved Mahavidyalaya, Gujarat Ayurved University, \\ Jamnagar, Gujarat, India \\ ${ }^{2}$ Associate Professor, Department of Kayachikitsa, I. P.G.T. \& R.A., Gujarat Ayurved University, Jamnagar, \\ Gujarat, India
}

Received on: 22/09/15 Revised on: 21/10/15 Accepted on: 13/11/15

*Corresponding author
E-mail: doctor_megha01@yahoo.com

DOI: $10.7897 / 2277-4343.07128$

\begin{abstract}
Ayurveda has paid significant attention to description of Jara (Aging) and consequences related to Jara. But there is no direct reference of incidence of Pandu Roga during old age. However, Acharya Sushruta stated that there is decline of tissues, sensory organs, strength, virilism after the age of 40 years. Acharya Charaka has revealed successive decline in the qualities of tissues in old age. These degenerative changes started in old age play a vital role in the development of Pandu Roga during old age and thus facilitate pathogenesis of Geriatric Anemia (Pandu roga in old age). Anemia is the commonest haematological abnormality among elder population. It should never be considered as normal physiological response to aging. Geriatric Anemia can have significantly more severe complications than anemia in younger adults. This review provides ayurvedic perspective of Geriatric Anemia (Pandu Roga in old age) in the light of contemporary science.
\end{abstract}

Keywords: Geriatric Anemia, Jara, Pandu Roga

\section{INTRODUCTION}

The disease Pandu Roga is called so because of the prominence of pallor in skin ${ }^{1}$. In Ayurveda, the word "Pandu" means a white colour mixed with yellowish tinge or pale ${ }^{2}$. This is an abnormal colour imparted to the skin due to decrease in Rasa (plasma/nutrient fluid) and Rakta (blood) in the body. Pandu Roga can be correlated with Anemia on the ground of its similar signs and symptoms. Thus, the term Anemia can be taken under the broad umbrella of Pandu. It has been vividly described with etiopathogenesis, clinical features, prognosis, management, etc. in the ancient texts. Acharya Charaka ${ }^{3}$ describes general clinical features of Pandu such as tinnitus, suppression of digestion, weakness, prostration, hatred of food, fatigue, giddiness, pain in the body, fever, dyspnoea, heaviness, and tastelessness. Patient feels as if all his limbs are being kneaded, squeezed and churned, swelling of orbits, falling of hair, loss of luster, irritability, dislike for cold, sleepy, excess expectoration, diminished speaking, cramps of calf muscles, pain and weakness in back, thighs and legs, dyspnoea on climbing up. Ayurveda has paid significant attention to description of Jara (Aging) and consequences related to Jara. But, there is no direct description of Pandu Roga during old age. But, various degenerative changes begin in old age is responsible for development of Pandu Roga during old age. Physiologically dominancy of Vata Dosha (one of the three organizing principles responsible for dynamic bodily function) and deficient state of Rasadi Dhatus during old age ${ }^{4}$ contribute susceptible environment to develop Pandu Roga during old age. According to modern science, Anemia is the commonest haematological abnormality among elder population. It should never be considered as normal physiological response to aging 5 . Further, advancing age is associated with decline in physiological functions and cause oxidative stress ${ }^{6}$. Anemia is generally overlooked in the elderly since such symptoms as fatigue, weakness, or shortness of breath may be attributed to the aging process itself. Results from a number of studies have indicated that anemia has a substantial negative impact on both function and quality of life in the elderly. Even when "mild" anemia is present, it is associated with both significant functional impairment and increased patient mortality ${ }^{7}$.

\section{Jara (Old Age/Aging)}

Whole lifespan is divided into three parts, i.e. Bala (childhood), Madhya (adulthood) and Jirna (old age) ${ }^{8}$. Vriddhavastha is the last phase of life, (60-70 years) signifies by its name and the word Jirna represents characteristics of this stage of life with degeneration.

The term Jara (aging) is indicative of state of old age 9 . It is indicative of loss in period of life span. The last phase of life span has been referred as Jara. It is described as a natural and inevitable processes as well as natural diseases. It is the substance which continuously trims down. It is also known as Vardhakya means the latter phase of life span. In routine, the word Jara is to be understood as a Vridhhavastha (Aging) or in the other meaning it should be taken as a declining of Ayu or Vaya $^{10}$.

\section{Physiological changes during old age}

According to ancient ayurvedic scholars old age is dominated by quantitative and qualitative decrease of all the Dhatus begin from the Rasa Dhatu (nutrient fluid, the first of the seven tissues of the body). Acharyas had great observation of body changes occurring during old age. They clearly distinguished somatic changes (including pathological conditions) from psychic variations. Somatic changes (with pathological conditions) like decrement in tissues, sensory-motor system, strength, virility, enthusiasm associated with wrinkles, graying, baldness, 
frequent attacks of cough, breathlessness, etc. and will be unable to do one's owns functions ${ }^{11}$. Acharya Charaka ${ }^{12}$ adds decline in mental faculties along with physical faculties likereduction in the capacity of perception, retention, recollection, speech and knowledge with dominancy of Vata during this age. Acharya Vagbhatta ${ }^{13}$ adds more to the above features i.e., this phase of life is accompanied with reduced digestive capacity and tremors. These all degenerative changes started in old age play a vital role in the development of Pandu Roga during old age. Old age is the emaciated condition that is described by Acharya Sushruta ${ }^{6}$ as a "Similar to an old rumbling house collapsing with the onset of rain."

As per Acharya Sharngadhara ${ }^{14}$, gradual declination of a particular faculty takes place in each decade of life and by the end of decade, that particular faculty is lost.

Table 1: Decade wise decline in faculty

\begin{tabular}{|c|c|c|}
\hline Sr. no. & Decade & Loss of faculty \\
\hline 1 & I & Childhood \\
\hline 2 & II & Growth \\
\hline 3 & III & Intellect \\
\hline 4 & IV & Skin \\
\hline 5 & V & Vision \\
\hline 6 & VI & Reproductive Capacity \\
\hline 7 & VII & Valour \\
\hline 8 & VIII & Knowledge \\
\hline 9 & IX & Motor organs \\
\hline 10 & X & Life \\
\hline
\end{tabular}

It is clear from above description that ageing does not occur simultaneously in all the tissues. Different body tissues are affected ageing at different time period.

\section{Systematic changes in old age: An Ayurvedic view}

\section{Effect of Jara on Tridosha}

Aging is a event characterized by decay and degeneration in which anatomical structures are basically affected following which physiology is also disturbed. Body is governed by Tridosha. (Vata, Pitta and Kapha) They govern the whole body and Vata is the strongest Dosha amongst three of them and is responsible for all the movements in the body ${ }^{15}$.

Vata is the most important factor to be considered in old age, obviously because of its natural predominance in old age. Since Vata is Niyanta ${ }^{16}$ means which governs the coherence of the components of life such as Sharira (body), Indriya (sensory organs), Sattva (mind) and Atma, Vata itself may be called as $\mathrm{AYU}^{17}$. Vata regulates the proper synthesis of tissue, joins the tissue proportion to form the organs and structure of the body. It helps in the production of speech, perception of touch and sound $^{16}$.

Vata Dosha is predominant in old age. Due to its own properties like Ruksha (dry), Laghu (light), Khara (rough) ${ }^{18}$ precipitates degeneration of tissue elements; it affects all the sense faculties, impaired complexion, happiness and the span of life, which are responsible for most of the manifestation of Aging. On the other hand, aging is responsible for diminution of Dhatu (tissues) which again responsible for increase of Vata Dosha. In short, old age is a predominant stage of Vata which causes degenerative changes which further facilitate pathogenesis of Pandu of Apatarpanaja type (under nourishment).

Effect of Jara (Aging) on Agni (digestive and metabolic fire) Agni (digestive and metabolic fire) is said to be responsible for the conversion of dietary substances into tissue elements. Acharya Charaka ${ }^{19}$ stated that Agni (digestive and metabolic fire) is the causative factor for life span, colour and complex, strength, health, enthusiasm, nourishment, growth and vigour. Old age leads to improper digestion and metabolism and thus is responsible for decrease in the absorption, metabolism and assimilation reducing the Prinana (nourishment) functions of the Rasa dhatu (nutrient fluid, the first of the seven tissues of the body). Further it influences proper formation of Rakta (blood) and thus might be responsible for Pandu in old age. ${ }^{20}$

In old age vitiated Vata leads to Vishamagni (erratic digestive fire) which is stated as a basis for Dhatu Vaishamya ${ }^{21}$ (nonequilibrium of the tissues) and does not perform its function of providing nutrition to the rest of tissues.

\section{Effect of Jara (Aging) on Dhatu (tissues):}

The classical texts have not detailed the role of individual Dhatu in the pathophysiology of aging. Ancient Acharyas universally noted gradual decline in the Dhatu with increasing age. Detail description about decline in Dhatu during old age is as below. According to ancient ayurvedic scholars old age is dominated by quantitative and qualitative decrease of all the tissues begin from the Rasa Dhatu. Acharya Charaka ${ }^{12}$ has considered gradual decline in the qualities of Dhatu (tissues) as a sign of Jara (aging). Acharya Vagbhatta ${ }^{13}$ also shares the same notion by stating 'Ksheeyamana Dhatu Guna' (decline in quality of tissues). Bhela Samhita throws further light in these regards. The capacity for Viveka i.e. discretion of assimilized nutrients in to Dhatu (tissues) is hampered due to decline in tissues. ${ }^{22}$ Therefore, the replacement of Dhatu (tissues) is also reduced as a result of already exiting vitiation. Moreover, it can further be assumed by the word "Viveka No Yatha Poorvam Vivichyate" (improper metabolism) might also result out of this. These definitely increase the accumulation of unwanted waste materials, which cannot be flushed out of the body. Production of the respective Dhatu (tissues) of low quantity is again another possibility due to such metabolism. By stating such an important factor, Acharya Bhela has apparently referred the incapacitation of Dhatvagni (tissue metabolism). Obviously enough, Ashtanga Samgraha ${ }^{13}$ has mentioned "Slatha Sara" (flabbiness of tissues) as one of the sign of Aging. Sara indicates the best state of individual tissues. In old age, he has said Sara is being disturbed this suggest disturbance in all the Dhatu (tissues).

In short, old age is associated with decline in all Dhatu (tissue) and it is beginning from Rasa Dhatu as a result of derange Agni (digestive and metabolic fire) during old age. This may not be able to form excellent quality of Rasa Dhatu (plasma/nutrient fluid) which leads to sequential decline in rest of the tissues. Therefore, the deranged Agni (digestive and metabolic fire) sets off a chain of malformation of subsequent Dhatu (tissue) and leads to Pandu Roga. Moreover, Acharya Charaka ${ }^{23}$ has mentioned Pandu Roga as one of the disease associated with the vitiation of Rasa Dhatu (plasma/nutrient fluid).

\section{Systematic changes in old age: A modern view}

Aging: Ageing is the progressive, universal decline first in functional reserve and then in function that occurs in organisms over time ${ }^{24}$. The biochemical composition of tissues changes with age, physiologic capacity decreases, the ability to maintain homeostasis in adapting to stressors decline, and vulnerability to disease processes increases with age. After maturation, mortality rate increases exponentially with age ${ }^{25}$.

\section{Age Related Changes in Haematopoietic System:}

The process by which the formed elements of blood develop is called Haematopoesis ${ }^{26}$. Blood cell production requires stem cells, a functioning bone marrow, micro environment, nutrients, cytokines and haematopoetic factor ${ }^{27}$. 
As individuals age, red cell size and membrane viscosity tend to increase while the red blood cell (RBC) lifespan tends to shorten from the standard 120 days. Aging is also accompanied by qualitative and quantitative changes in haematopoiesis with an overall reduction in stem cell concentration, hematopoietic growth factor production, and a reduced sensitivity to erythropoietin $^{28}$. Moreover, marrow shows haematopoetic changes due to ageing like decreasing in the number of committed stem cells and increasing in the fat content ${ }^{29}$. Besides this, there is strong evidence that many inflammatory markers increased in elderly population regardless of health status ${ }^{30},{ }^{31}$. Inflammatory markers are inducers of hepcidin secretion, implicated in mediating iron limited erythropoesis, thus contributing common path way for development of anemia $^{32}$. All these factors make elderly more prone to develop anemia.

Age related other changes

Age related anatomical changes like intestinal wall atrophy, reduced blood supply, and intrinsic neuronal changes within the lower gastrointestinal tract may contribute to delayed transit time and decreased stool water content. All these changes are due to morphological atrophy of mucosa, intestinal glands, and muscularis in normal aging process which leads to decreased interstitial motor activity and decreased intestinal motility which ultimately cause constipation. ${ }^{33}$ Constipation causes inadequate absorption of nutrient substances because due to constipation there are sluggish peristaltic movements. It results in deficiency of nutrition from the G.I.T and thus play key role in manifestation of Nutritional Anemia in old age ${ }^{34}$.

\section{Adverse Outcomes of Anemia in Elderly}

Geriatric Anemia can have significantly more severe complications than anemia in younger adults. Geriatric anemia has been associated with increased frailty, poor exercise performance, diminished cognitive function, risk of developing dementia, increased risk of recurrent falls, increased rate of major depression, cardiovascular diseases and increased hospitalization ${ }^{28}$.

Probable pathogenesis of geriatric anemia (pandu roga in old age)

Pathogenesis of Pandu Roga can be divided into two part - (1) Pandu Roga due to Santarpana (over nourishment) (2) Pandu Roga due to Apatarpana (under nourishment)

However, Acharya Charaka has categorized Pandu under Santarpana (over nourishment). But, old age is associated with degenerative changes hence it can be understood as Apatarpana Janya (under nourishment).

Thus, we can say that Dhatu-Kshaya (degeneration of tissue) and causes related to Apatarpana (under nourishment) are unavoidable condition of the Pandu Roga in old age. Flowchart of pathogenesis shows the probable pathogenesis of Pandu Roga during old age. Detail description of it is mentioned as below. (Figure 1)

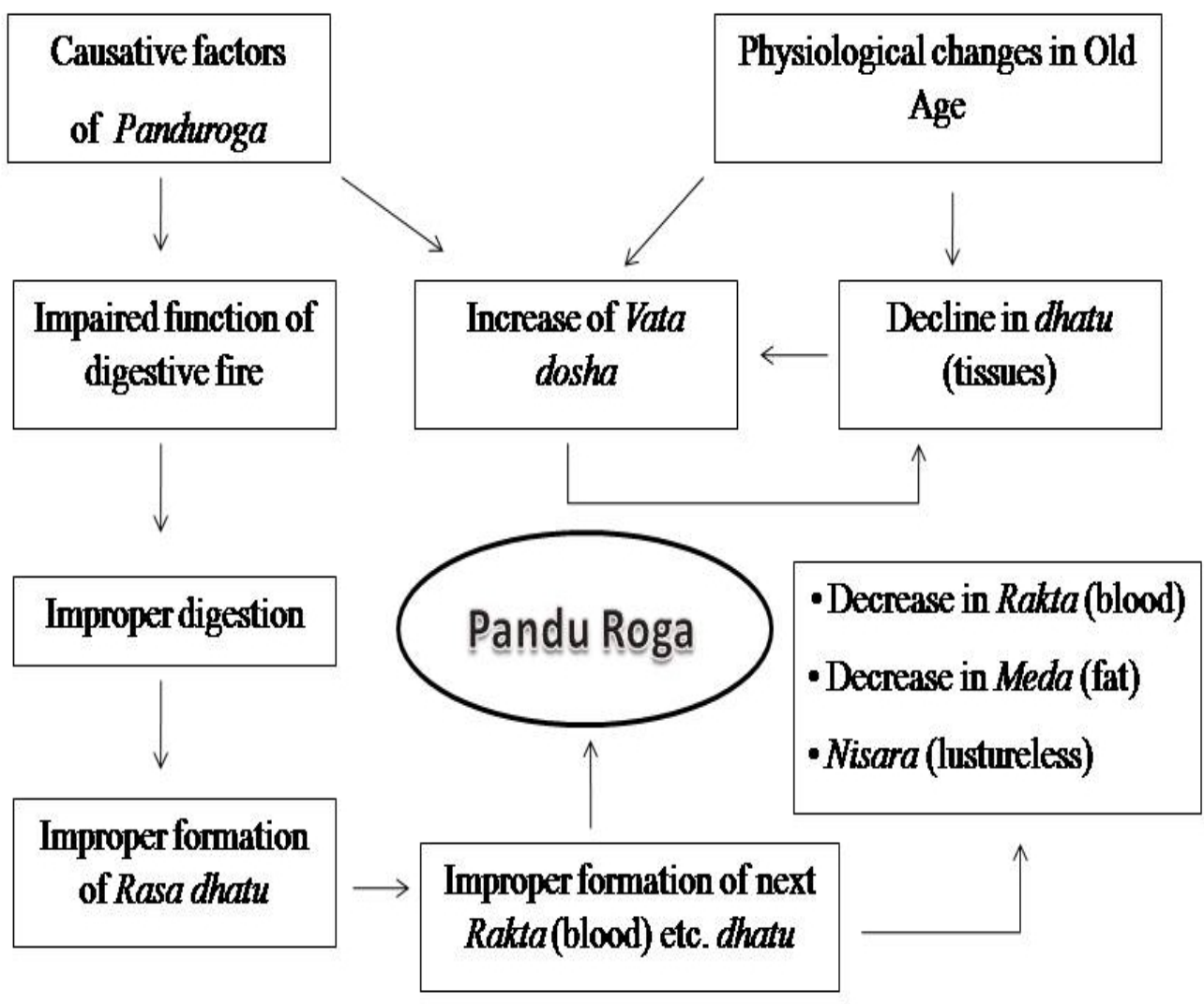

Figure 1: Probable Pathogenesis of Geriatric Anemia (Pandu Roga in old age) 
In old age, all tissues undergo degeneration, thus leading to Vataprakopa (increase in Vatadosha). Dhatu kshaya (degeneration of tissue) further increases Vata dosha in elderly, where Vata is in already increased condition. Further, in old age, etiological factors like Ativyayama (excessive physical exertion), Ratrijagarana (night awakening), Chinta (anxiety), Shoka (grief), Krodha (anger) etc. increase Vata Dosha. On the other hand, these etilogical factors disturb digestion. Agnimandhya (weakened digestive fire) is also developed due to vitiation of Vata Dosha, which hamper the digestion. Ultimately, Rasa Dhatu does not form properly due to improper digestion. Ahara Rasa (plasma/nutrient fluid, the first of the seven tissues of the body) is the source for the formation of all the tissues. This Rasa which is the resultant of the proper digestion circulates through the micro channels and leads to the formation of all the Dhatu. The immediate Dhatu to be nourished by the Rasa is the Rakta (blood). In the chapter of Pandu, Acharya Chakrapani $^{35}$ clearly mentions the role of Rasa in the nourishment of the Rakta (blood). He comments that the RaktaKshaya (reduction in blood) is due to the diminution of the Rasa (plasma/nutrient fluid) by the increased Pitta or the failure of the Rasa (plasma/nutrient fluid) to produce the Rakta Poshaka part (nourishing portion).

So, Rasa Kshaya (reduction in rasa dhatu) leads to diminution of Rakta (blood) which is further responsible for decline in subsequent tissue upto Shukra (semen) and Oja (the essence of the seven tissues and thus producing symptoms like Alpa Rakta (deficiency of blood), Alpa Meda (deficiency of fat), Nihsara (lusterless), Shithilendriya (looseness of body parts) etc. and thus Pandu Roga develop.

\section{CONCLUSION}

Old age is an unavoidable phase of human life disturbing in the equilibrium in all the three Doshas with dominancy of Vata Dosha. Vata dosha is the most important factor in the pathophysiology of ageing obviously because of its natural predominance at that stage of life. The combination of dominant state of Vata Dosha, deterioration of Rasadi Dhatu and disturbed state of Agni (digestive and metabolic fire) are responsible for the various degenerative changes and process of decay in the body which result in development of Pandu Roga during old age.

\section{REFERENCES}

1. Susruta Samhita, Ayurveda Tatva Sandipika, Hindi commentary, Edited by Kaviraja Ambikadutta Shastri, Uttaratantra, Panduroga Pratishedha Adhyaya,44/ 4 Chaukhambha Sanskrit Sansthan, Varanasi, Reprint-2005, p. 285

2. Sir Monier Williams, A Sansrkrit English dictionary, Reprint, Sri Satguru Publications, a division of Indian Books Centre, Delhi,2005, p. 616

3. Charaka Samhita, Edited by Vd. Jadavji T. Acharya, with Ayurveda-Dipika Commentary by Chakrapanidatta, Chikitsa Sthana, Pandurogachikitsita Adhyaya, 16/13-16, Chaukhamba Surbharati Prakashana, Varanasi, $2^{\text {nd }}$ edition, 2005; p. 527

4. Sureshbabu S., Geriatrics in Ayurveda: Chaukhambha Orientalia; Varanasi, $1^{\text {st }}$ edition, 2001, p. 8

5. D. Mukhopadhyaya, K Mohanaruban, Iron deficiency Anemia in older people: Investigations, management and treatment, Age and Aging: British Geriatric Society, 2002;31:87-91.

6. K. Mallikarjuna, K. Nishanth, T. Bhaskar Reddy, K. Sathyavelu Reddy, Alterations of Intra and Extra
Mitochondrial Enzyme in the Muscle Fibers of Rat Hind Limbs: role of Exercise Training Under Age InducedOxidative Stress Conditions, Indian Journal of Gerontology, 2007; 22 (1):1 - 13

7. http://www.srl.in/rd/innersense/Voice84.pdf accessed on $17 / 9 / 2015$

8. Ibidem (1), Susruta Samhita, part I, Sutra Sthana, Aturopakramaniya Chapter 35/34, p. 134

9. Ibidem (2), Sir Monier Williams, A Sansrkrit English dictionary, p. 414

10. Megha Pandya, Alankruta Dave, "A Comparative Study of Pandu Roga in Old Age (Geriatric Anemia) and its management with Amrutarnava Rasa and Punarnava Mandura", Ph.D. thesis, Kayachikitsa dept. 2009, IPGT \& RA, Jamnagar.

11. Ibidem (1), Sushruta Samhita, Sutra Sthana, Aturopakramaniya Adhyaya, 35/36, p.135

12. Ibidem (3), Charaka Samhita, Vimana Sthana, Rogabhishagjitiya Adhyaya 8/122, p. 280

13. Astanga Sangraha, Sashilekha Sanskrita Commentary by Indu, Edited by Dr. Shivprasad Sharma, Sharira Sthana, Prakruti Bhediya Shariram, 8/24, Chaukhabma Sanskrit Series Office, Varanasi, $1^{\text {st }}$ edition, 2006, p. 330

14. Sarngadhara Samhita, English translation by Murthy P.H.C. Purva khanda, Aharadi Kathana $6 / 18,1^{\text {st }}$ edition, 2001, p. 77

15. Ibidem (14), Sarngadhara Samhita Purvakhanda, Kaladikakhyana Adhyaya, 5 / 25, p. 44

16. Ibidem (3), Charaka Samhita Sutra Sthana, Vatakalakaliya Adhyaya, 12/8, p. 80

17. Ibidem(3),Charaka Samhita Chikitsa Sthana, Vatavyadhi Chikitsita Adhyaya, 28/3, p. 616

18. Astanha Hridaya, Commentaries, edited with Vidyotini, Hindi Commentary by Kaviraj Atridev Gupta, edited by Vd. Yadunandana Upadhyaya, Sutra Sthana, Ayushkamiya Adhyaya, 1/10, Chaukhambha Sanskrit Sansthan, Varanasi, $14^{\text {th }}$ edition, 2003, p. 8

19. Ibidem (3), Charaka Chikitsa Sthana, Grahanidosha Chikitsita Adhyaya, 15/3-4, p. 512

20. Madhavi Mahajan, A.V. Joshi, An interrelation between mild cognitive impairment and acid reflux syndrome, International Journal of Multidisciplinary Research and Development, 2015;2(7):297-300

21. Ibidem (3), Charaka Samhita Chikitsa Sthana, Grahanidosha Chikitsita Adhyaya, 15/50, p. 517

22. Bhela Samhita, Dr. K.H. Krishnamurthy, edited by Prof. Priyavrat Sharma, Sharira Sthana, Manoavatisthte Adhyaya 2/4-5, Chaukhambha Vishvabharati, Varanasi, reprint 2008, p. 196

23. Ibidem (3), Charaka Samhita Sutra Sthana, Vividhashitapitiya Adhyaya, 28/10, p. 179

24. Harrison. Principles of Internal Medicine. Mc Graw Hill Medical Publication; New Delhi: $17^{\text {th }}$ edition, 2008. Ch. 9, p.53.

25. Vandana Gupta, Bipin Bihari Keshari, Narasimha Murthy, KHHVSS. Concept of Jara (ageing) and its management in Ayurveda. Ayurpharm, Int J Ayur Alli Sci. 2013; 2(11): 341-349.

26. Gerard J. Tortora, Bryan Derrickson, Principles of Anatomy and Physiology, John Willey \& sons, Inc, $11^{\text {th }}$ edition, 2006, chp. 19 , p. 670

27. M. Rama Devi, C Jaya Bhaskar, M.S.Sridhar, Shankar Reddy Dudala , Anaemia In The Elderly - An Emerging Health Problem (A Neglected problem) 2015;14(2):51- 58

28. Dharmarajan T S, Pais W, Norkus EP. Does anemia matter? Anemia, morbidity, and mortality in older adults: Need for greater recognition. Geriatrics, Dec.2005; 60(2), p.2-29 
29. Stander, Anemia in the elderly; symptoms, cause and therapies, Post graduate Medicine,1989;85: p.85- 87

30 . Ferrucci et al, The origin of age related pro inflammatory state. Blood. 2005: 105, p. 2294- 2299

31. Krabbe et al. Inflammatory mediators in the elderly. Exp. Gerontology, 2004, 39, p. 687- 699.

32. Ganz T. Hepcidin, A key regulator of iron metabolism and mediator of anemia of inflammation, Blood, 2003; 102: p. $783-788$

33. Lingu Inya, Kulkarni Prasad V, Tanna Ila, Chandola HM. Evaluation of diet, life style and stress in the etiopathogenesis of constipation in geriatric people. Int J Res Ayurveda \& Pharm. 2012; 3(5):879-883
34. http://www.innvista.com/health/nutrition/diet/absorb.htm accessed on $3 / 9 / 2015$

35. Ibidem (3), Commentary of Chakrapani on Charaka Samhita Chikitsa Sthana, Panduroga Chikitsa Adhyaya, 16/6, p. 526

\section{Cite this article as:}

Megha G. Pandya, Alankruta R. Dave. Understanding of geriatric anemia (pandu roga in old age): An Ayurvedic perspective. Int. J. Res. Ayurveda Pharm. Jan - Feb 2016;7(Suppl 1):49-53 http://dx.doi.org/10.7897/2277-4343. 07128

Source of support: Nil, Conflict of interest: None Declared

Disclaimer: IJRAP is solely owned by Moksha Publishing House - A non-profit publishing house, dedicated to publish quality research, while every effort has been taken to verify the accuracy of the content published in our Journal. IJRAP cannot accept any responsibility or liability for the site content and articles published. The views expressed in articles by our contributing authors are not necessarily those of IJRAP editor or editorial board members. 